\title{
Factors contributing to changes in food practices of a black South African community
}

\author{
Annemarie T Viljoen, Priscilla Botha and C C Boonzaaier
}

\section{OPSOMMING}

Merkbare veranderinge in die lewenstyl van die swart bevolkingsgroepe in Suid-Afrika is die afgelope vier dekades waargeneem. Voedselpraktyke as deel van lewenstyl het gevolglik ook verander. Onlangse publikasies waarin hierdie veranderinge gerapporteer word, benadruk die voeding- en gesondheidsrisiko's wat hierdie veranderinge tot gevolg het, en betreklik min aandag word gegee aan die veranderende voedselpraktyke wat daarmee gepaard gaan. Gevolglik is daar beperkte inligting oor die voedselpraktyke van die verskillende etniese groepe in Suid-Afrika bekend, aangesien die klem grootliks geplaas word op wat geëet word. Ten einde sinvolle voeding-onderrig en -intervensies te kan deurvoer behoort daar ook insig en begrip te wees vir waarom mense eet wat hulle eet.

' $n$ Studie met die doel om die huidige voedselpraktyke asook die betekenis wat aan voedsel geheg word, te verstaan, beskryf en verduidelik, is onlangs in die Mmotla gemeenskap, $55 \mathrm{~km}$ noordwes van Pretoria, uitgevoer. Een van die doelwitte van die studie was om die huidige eetpatrone (maaltydpatrone en -samestelling) te beskryf, asook hoe hierdie patrone ontwikkel en verander het. In hierdie artikel word die eetpatrone van die Mmotla gemeenskap beskryf tesame met die redes waarom hierdie praktyke tans gevolg word, en dit word ook in verband gebring met die gerapporteeerde voedselpraktyke in die literatuur.

' $n$ Kwalitatiewe navorsingstrategie is gevolg en data-insamelingstegnieke soos fokusgroepbesprekings, individuele onderhoude en deelnemende waarneming is gebruik. Die vroulike inwoners van Mmotla was die teikenpopulasie en verskeie etniese groepe waaronder die Ndebele, Noord-Sotho, Tswana, Tsonga, en Swazi was verteenwoordig in die gemeenskap. Die onderhoude en besprekings is op band vasgelê en verbatim transkribeer, en aangevul deur volledige veldnotas. Die data-ontleding is met behulp van die rekenaarsagtewareprogram Atlas.ti uitgevoer, en die "grounded theory"benadering is gevolg.

Die maaltydpatrone en -samestelling gedurende weeksdae en oor naweke is weergegee. Die prosedure by die bediening van maaltye en die tipe voedsel wat tydens spesiale geleenthede en feesvieringe bedien word, word uitgelig. Aspekte wat ' $n$ direkte invloed op die huidige praktyke het, is voedselverkryging, toegang tot elektrisiteit, die beskikbaarheid van inheemse groente, en die bekostigbaarheid en beskikbaarheid van voedsel. Sosio-kul- turele invloede waaronder die invloed van die blankes, gerief, die kerk, belangrikheid van etniese identiteit, gesondheid en opvoeding blyk ook belangrike bydraende faktore te wees. Die bydraes van hierdie invloede op verandering van die tradisionele na die huidige praktyke word gerapporteer, en die belangrikste invloede blyk die onmiddellike omgewing (natuurlike sowel as mens-gemaakte), tesame met ekonomiese en sosio-kulturele faktore te wees. .

\section{- Mrs AT Viljoen}

Department Consumer Science University of Pretoria

\section{- Prof P Botha}

Department Consumer Science

University of Pretoria

\section{- Prof CC Boonzaaier}

Department Anthropology and Archaeology University of Pretoria

\section{INTRODUCTION}

The South African society is in a process of radical change, and one of the greatest changes that have been observed is in the life-styles of the black population groups, where a shift from the traditional life-style to a partially Western-oriented life-style is noticed. Food practices (including food choices and food consumption patterns as well as food related behaviours), which can be considered as part and parcel of lifestyle, are therefore also subject to change (Oltersdorf et al, 1999; Grunert, 1993). A gradual shift towards the Western-oriented diet by black South Africans has been reported over almost the past four decades (Bourne \& Steyn, 2000; Labadarios, 2000; Labadarios et al, 1996; Van Eeden \& Gericke, 1996; Bourne et al, 1994; Crous \& Borchardt, 1982; 1984; 1986; Manning et al, 1974; Lubbe, 1971; Leary, 1969; Oudkerk, 1965). These changes can be attributed amongst others to migration, urbanisation, acculturation, education and economic development (Walker \& Charlton, 2001; Labadarios et al, 1996; Walker, 1995; Bourne et al, 1993).

Gradually the indigenous African people of South Africa upon contact with Western-oriented societies not only adopted some aspects of the Western food system, but also adapted and changed their traditional food practices with their increased exposure to Western foods. This interaction with the Western-oriented 
food ways resulted in a process of "Nutrition in transition" (Bourne \& Steyn, 2000; Nestle et al, 1998; Labadarios et al, 1996; Walker, 1995; Bourne et al, 1994; Bourne et al, 1993). An unfortunate characteristic of nutrition transition is that people become "acculturated into preferring and consuming a diet high in fat" (Nestle et al, 1998). Popkin (1994) raised the same concern with regard to the "shift in the composition of diets" in developing countries that shows a tendency towards an increased consumption of saturated fat, sugar and refined foods - with a resultant lower fibre intake.

These undesirable outcomes of acculturation and urbanisation usually culminate in increased mortality and morbidity rates as a result of chronic noncommunicable diseases typically associated with the Western life-style (Walker \& Charlton, 2001; Labadarios et al, 1996; Walker, 1995; Bourne et al, 1993). It is expected that the occurrence of these degenerative diseases will continue to rise and an increased burden will be placed on the public health services in South Africa (Labadarios et al, 1996; Walker, 1995; Bourne et al, 1993). A strong emphasis is therefore placed on the investigation into the nutrient content of the diets of the different population groups and the composition of risk profiles for chronic non-communicable diseases among the different South African population groups.

The recent South African studies quoted above, however, only reported on the nutrient content of the diets and the health consequences of these diets for specific groups in the South African population. The current knowledge base on the food practices of the South African population as a whole, is however still fragmentary. Current research mainly deals with what is consumed, i.e. meal composition, meal patterns and the nutrient content thereof, and results with regard to the food practices in South Africa therefore predominantly provide information on what some sectors of certain population groups eat.

To be able to deliver meaningful nutrition education and intervention programmes as well as effective consumer facilitation to all South Africans, a thorough understanding of why people use and consume the food they do is also needed. To be able to better understand the reasons for food choices an in-depth knowledge of the food choice processes and food practices is needed (Croll et al, 2001; Paisley et al, 2001; Reynolds et al, 1999; Falk et al, 1996). Knowledge of the socio-cultural, historical, and demographic factors contributing to these is also advisable for a holistic approach (Nestle et al, 1998). In this regard, South African researchers also recommended a holistic approach that would include a sound knowledge of the food habits of the different population groups for successful nutrition interventions in South Africa (Van Eeden \& Gericke, 1996; Bourne et al, 1993). Since these recommendations were made, limited research was initiated or reported, in reputable journals on the South African population. There is therefore a real need to investigate the factors that may contribute to changes in the food practices of the different South African population groups.
A study with the overall goal to understand, describe and explain the current food practices and the meanings attached to them, was undertaken amongst selected members of a black South African community residing in a densely populated area $55 \mathrm{~km}$ north-west of Pretoria, in the vicinity of the Tswaing Meteorite Crater. One of the objectives of this cross-cultural study was to determine the current eating patterns (meal patterns and composition of meals) of this group and how and why these have developed or changed over time. In this article the current eating patterns in this community will be reported and placed into context with the reported changes in the food practices of black South Africans as reported in literature, and possible explanations for the changes will be offered.

\section{RESEARCH DESIGN}

A qualitative research strategy was followed employing various qualitative research techniques in this explorative, descriptive and explanatory study to reach the set research goal and objectives. Focus group discussions, individual interviewing, participant observation and selected techniques from the Participatory Rural Appraisal (PRA) methodologies were used as data collection techniques. These techniques were considered appropriate to answer the research questions as formulated, and were chosen to complement and reinforce each other and to aid in triangulation. Each technique as such provided the means to view the problem from a different point of view (Babbie \& Mouton, 2001:275; Strauss \& Corbin, 1998:11; Trollip, 1995; Miles \& Huberman, 1994:438).

Food practices are complex and multidimensional, and as such necessitated that the data collection be conducted in two phases. During the first phase of the data collection, the aim was to get acquainted with the participants, their current food practices and the structural environment of the village. The structural environment included aspects of the natural and manmade physical environment, political influences, economic situation and the available technological resources of the village. To become familiar with the research setting, techniques from the PRA method, focus group discussions (FGDs) and participant observation were employed. The second phase dealt with data collection on the socio-cultural environment and the personal domain of the participants, which was done by means of individual interviewing.

\section{Gaining access}

Access to the community was gained through a colleague who was involved in a beadwork incomegenerating project in the community. A negotiating / introductory meeting was held with the members during which the aim of the research and the research procedure were explained to them.

\section{Sampling}

Target population Female residents in the Mmotla community were the target population. The population composition consists of various ethnic groups, such as 
the Ndebele, Tswana, Northern Sotho, Tsonga and Swazi. Although the Mmotla community is composed of various ethnic groups, all the informants were fluent in Tswana, which is used as the local language. Although they were fluent in Tswana, most informants in this study could be described as having low literacy skills.

Sampling technique The sampling technique associated with qualitative research is that of nonprobability sampling (Babbie \& Mouton, 2001: 166; Neuman, 2000:196) and, as explained by Neuman (2000:196), the purpose of non-probability sampling is "... to collect specific cases, events, or actions that can clarify and deepen understanding". This sampling technique is therefore less concerned with representativeness and deals more with the relevancy of the chosen persons to the research topic (Flick in Neuman, 2000:196). Other authors such as Hammersley and Atkinson (1995:45) and Miles and Hubermann (1994:30) also refer to the importance of matching the cases with the research problem of a study. Babbie and Mouton (2001:288) explain that a smaller sample may often be used in the interpretative research paradigm because "sampling is often purposeful and directed at certain inclusive criteria rather than random".

Different techniques of sampling were employed for each phase of the data collection and different criteria were set for selecting informants in each of the phases. In the first phase, FGDs were used to "explore" and become acquainted with the community and to gain an understanding of the life-world of the informants (De Vos \& Fouché, 1998:81), to get a broad overview of the food practices of the community, and lastly to determine to what extent modern and traditional food practices were followed. In the second phase, various individual interviews were conducted with "thoroughly enculturated" (Spradley, 1979:47-51) informants, because the objective was to gain greater and deeper insight into the traditional and modern food practices of this community.

Selection of informants Four FGDs were held during the first phase of the data collection. Three groups comprised adult females, and the fourth group consisted of grade 11 and 12 school girls. Volunteers who were available on the weekdays that the researcher could visit the village formed the first group. During the first phase of the data collection and specifically the FGD with the first group, the researcher tried to "keep the collection process open to all possibilities" - according to the guidelines of Strauss and Corbin (1998:206). This implied that, when sampling during the initial phase of a study, the researcher should be "open to those persons, places and situations that will provide the greatest opportunity for discovery". In the first group, informants represented all the major ethnic groups residing in the village. For the second and third focus groups, purposive or judgemental sampling, as described by Babbie and Mouton (2001:167) and Neuman (2000:199), was employed. This was done to ensure that the informants engaged in the focus groups complied with criteria that were set according to the aims of the FGDs.
The criteria set were to include informants from all ethnic groups in the community, and the sample was therefore selected purposively to include specialists and laypersons from all the major ethnic groups residing in the community (Turner, 1967:27-43). Specialists were able to supply more objective and comprehensive information, while laypersons were able to relate action-field information from their own subjective viewpoint as informants in rituals and ceremonies. Care was taken to include specialists such as izinyangas or zangomas (traditional healers) and older females, especially those who still adhere to traditional beliefs and practices, as well as those who have knowledge of earlier social customs. Ordinary people who are knowledgeable on traditional customs and food practices and who still participated in traditional rites and ceremonies were regarded as laypersons. To be able to ensure that sufficient data on the traditional and the modern food practices were captured, the aim was to include young as well as older adult females, as well as more educated and less educated persons. The focus group with eight schoolgirls was formed to get the younger females' perspective on the traditional and the modern food practices. It was decided to include this age group of 16-18 years because at this age, young people already have established ideas about their food habits and food preferences and are able to communicate them (Story et al, 2002; Woodward et al, 1996; Ton Nu et al, 1996).

The adult informants were recruited from the incomegenerating project and from learners who attended literacy classes for adults. Three focus groups were formed, with a total of 35 adult informants. The number of informants in each group who attended the discussions ranged from 8 to 12 informants per group. Between 9 and 11 focus group sessions were needed to cover all the topics with each of the three adult groups. After conducting FGDs with the three adult groups and the school girls, the researcher had a broad and general overview of the food practices currently followed in the community as well as the extent to which the traditions and customs of each of the ethnic groups represented in the focus groups were still practised.

In the second phase of the study, the individual interviews were conducted to be able to gain a deeper understanding of the traditional and current food practices in this community. Six informants were identified as suitable interviewees for the individual interviewing on the grounds of their cultural knowledge and life experience. The non-probability technique of theoretical sampling was employed for the selection of the participants for the individual interviews. This type of sampling is indicated during the process of data analysis when the grounded theory approach is used, and the rationale for the sampling is based on the emerging concepts transpiring during the data analysis that "have relevance to the evolving theory" (Strauss \& Corbin, 1998:202). This implies that during the research process the theoretical interest that develops or the new insights that are gained will guide or steer the decision of what data needs to be collected next and where the data could be collected (Neuman, 2000:200; EM Schurink, 1998:254). 
In selecting the sample for the FGDs and individual interviews the sample extensiveness was determined by how soon theoretical saturation and information redundancy was reached.

\section{Data collection}

Focus group discussions (FGDs) Phase 1 of the data collection started with the FGD as the "exploratory technique", because it was believed that this was an appropriate technique for this crosscultural study, through which the researcher would be able to get acquainted with the informants and become familiar with the food practices followed by individuals and groups in the community. This approach was in line with Morgan's (1997:22) recommendation that FGDs could be a good starting point for individual interviews where either the topic of discussion or the informants were unfamiliar to the researcher. It can also help in identifying individuals that would be suitable as informants in the individual interviews, because focus groups are useful to "reveal the range of the future informants' thoughts and experiences prior to the first individual interview".

Apart from being an excellent data collection technique in exploratory studies or in studies where process evaluation is important (Betts et al, 1996), the FGDs is also an effective technique to obtain data from adults with low literacy skills (Betts et al, 1996; Keim et al, 1999). Other advantages of FGDs relate to the cultural background of the informants and the type of data that can be obtained. In cross-cultural studies, FGDs seemed to be acceptable to cultural groups where a high premium is placed on group participation, because it seemed as if the informants were more at ease when they were interviewed in a group as opposed to individually. In this study this was the case in the beginning of the data collection phase. Trollip (1991:77) reported the same experience with a group of Ndebele women, and ascribed this to the cultural background of the informants, where the group and group participation was important, and argued that this could be a reason why this technique was also successful in her research.

Participant observation and PRA Through the process of participant observation, in which the researcher adopted the role of peripheral member as described by Adler and Adler (1987:36-39), the researcher had the opportunity to observe the informants in their own natural environment. The researcher got involved in the life-world of the subjects by conducting the research in the natural environment of the informants, namely the village of Mmotla. During these visits, the researcher had to drive through the village to reach the informants and venues where the FGDs and interviews were conducted. This gave the researcher an opportunity to observe the informants in their natural environment and to enquire, observe and record data relevant to the research problem. Data regarding the structural environment were mainly obtained by this technique and this included data on the natural surroundings and available resources that had an impact on the food practices of the participants. Data was collected through various techniques including looking, listening, enquiring and recording. The data collected obviously included the researcher's interview transcriptions and field notes (observational notes, theoretical notes and methodological notes). Other material such as photographs, video recordings, newspaper articles, and other documents and artefacts produced by the informants or others, which were readily available in the field setting, were also collected, viewed, photographed or copied with the permission of the informants, as advised by Jorgensen (in WJ Schurink, 1998:284).

To further the holistic and contextual approach of this study, selected techniques of data collection from the PRA approach were also used to gather data. The PRA approach was developed to actively involve members from rural communities in data collection to enable researchers to explore the unique local knowledge that indigenous people possess with regard to their own situation as well as the local context of the community (Collins, 1999:102). These techniques rely on the perspectives of the informants regarding their own situation and environment (Babbie \& Mouton, 2001:320). Data on the structural environment was for example obtained by using this technique. As indicated by Wetmore and Theron (1998), the researcher learns directly on site, and also face to face from the participants. Through this process local physical, technological and social knowledge was gained. These techniques have been found to be especially suitable for subjects who have a low literacy level or are illiterate (Trollip, 1997).

Individual interviewing During the second phase of the data collection process, individual interviewing was used as data collection technique. The purpose of individual interviewing was to obtain the informants' personal perceptions of their food practices and the meanings attached thereto, through carefully planned, semi-structured conversations. Although a list of topics were at hand to guide and remind the researcher what had to be covered in each interview, the list of topics was not used in a prescriptive manner. A degree of flexibility was maintained and the discussions were in the form of conversations. Each was adapted to promote the natural flow of the conversations, because the purpose was to obtain an in-depth understanding of some topics that were only broadly discussed in the FGDs with knowledgeable persons. It further provided the opportunity to delve deeper and "provide perspectives that were underrepresented in FGDs". The individual interviews also gave knowledgeable informants the opportunity to elaborate on topics that were not fully uncovered or explored in the FGDs (Morgan, 1997:23).

Following the advice of Falk et al (1996), all first interviews were based on the same interview guide. Guides for the second and following interviews were developed after transcription and preliminary analysis of the first interview, and were personalised for each informant. Emerging themes were covered in the second and successive interviews. 


\section{Procedures during FGDs and individual interviews}

The duration of the focus group discussions and individual interviews ranged from 90 to 120 minutes each. As a result of the language barrier between the researcher and the informants, a male and female interpreter who were both fluent in English and Tswana, assisted the researcher in the data collection. The female interpreter performed the role of interpreter and facilitator during the discussions. The male interpreter also acted as scribe and took notes in English of the discussions between the informants that were mostly in Tswana. These notes then also served as a back-up recording of the main points that were discussed. This was valuable as some discussions were very lengthy and involved, and sometimes the interpreter left out or forgot something that was mentioned and it could then be retrieved and added. The researcher directed the questions to the female interpreter who then posed the questions to the informants in Tswana. Exchanges between informants in the focus group were also in Tswana. This was then translated back into English for the researcher. The scribe also assisted from time to time at the request of the female interpreter to assist her with the translations and explanations. To guide the discussions, a semistructured interview schedule was used. Open-ended questions on specific themes and topics were typed out and copies were made available to the interpreters. This helped and ensured that the interpreters understood the aspect that was under discussion and also aided in translating the probes / questions more accurately. Both the FGDs and the individual interviews were audio-taped.

\section{Transcriptions}

Verbatim transcriptions were made of the audio-taped FGDs and interviews. Impressions and observations from the researcher's field notes and the notes kept by the scribe were added to the transcripts. An independent person, who was fluent in Tswana and English and who stood outside the context of the study, checked the transcriptions for accuracy as well as completeness of the translations.

\section{Data analysis}

The grounded theory approach of data analysis as outlined by Strauss and Corbin (1998:55-241) was employed, using the qualitative software package Atlas.ti. Data analysis continued throughout the study and the analysis procedures included open, axial and selective coding to identify the emergent themes and the relationships between the themes. Each new data set from each of the FGDs and the individual interviews were compared with the existing data. New themes that emerged and those already identified were used to compile aggregated descriptive summaries of the practices and procedures as they related to the food practices of this community. These summaries served as another form of data reduction and preliminary analysis (Achterberg, 1988). The transcriptions, field notes and observations were hereby put together in a more coherent, systematic and organised manner - thus contributing to a data set that was easier to handle and work from.

\section{FINDINGS AND INTERPRETATION}

\section{Biographic profile of participants}

Thirty-five adult females $(\mathrm{N}=35)$ participated in the FGD represented by the Ndebele $(n=17)$, Northern Sotho $(n=4)$, Swazi $(n=2)$, Tsonga $(n=6)$ and Tswana $(n=6)$ ethnic groups. Six females participated in the individual interviewing, of whom four were identified during the FGD. The mean age of the participants was 57 years and ranged from 25 to 76 . Eight schoolgirls between the ages of 16 and 18 formed a separate FGD to determine the younger generation's food practices.

\section{Current food practices}

A description will be given of the meal patterns and the composition thereof as consumed on weekdays and weekends as reported by the participants themselves. This will be compared to the published literature on the meal patterns and food choices of the black South African population, to explicate the changes that have taken place during the past century. Other related aspects to food practices such as the acquisition, preparation, storage and preservation of the food, as well as the serving of meals and celebrations will also be included.

\section{Current meal pattern and composition of weekday} meals The informants revealed that they ate three meals a day with in-between meal snacking during weekdays. The following meal pattern and composition was indicated:

Breakfast This meal can be described as a breadbased meal for most. Tea and brown bread seemed to be popular. The brown bread was consumed as such or with either margarine, peanut butter, jam, egg or tomato-and-onion gravy as a spread or accompaniment. Alternatively a soft porridge prepared from either maize-meal or sorghum-meal was enjoyed. This was served with milk and or sugar.

In-between meals Beverages such as tea, cordials, milk or only water were often consumed. Fruit such as oranges and apples were also enjoyed as snack.

Lunch Some participants indicated that they would again only have bread for lunch, with an accompaniment as indicated for breakfast. It was explained that most people who work as well as some of those who stayed at home, had bread for lunch. However, others who worked or stayed at home, ate stiff maize-meal porridge with some kind of relish. The relish was either vegetable-based or protein-based. The following vegetable-based relishes were indicated: morogo (prepared from indigenous or wild greens), spinach, cabbage and potatoes or tomato-and-onion gravy or achaar. Summer crops, when available, such as Maraca (an indigenous kind of summer squash) or maize on the cob were also mentioned as items on the sum- 
mer menu. The most popular protein-based relish was moatwana (also known as chicken runners - a stew prepared from chicken feet). Other relishes prepared from indigenous beans were also mentioned; however, these were only used when the ingredients were available.

Supper Stiff maize-meal porridge with a vegetable and/or protein-based relish was served at supper, the main meal of the day. The vegetable-based relishes were similar to those prepared for lunch and this seemed to be the general practice. Offal products from either chicken or beef, mostly intestines, were frequently served on weekdays at this meal. It was revealed that meat such as beef or chicken could be included; however, this only happened occasionally during weekdays as this was served more often over weekends. Tea as beverage was often consumed after supper.

\section{Current meal pattern and composition of weekend} meals There was a noticeable difference between meals served on Saturdays and Sundays and those served during weekdays. A larger variety of items and more expensive foods seemed to be included over weekends.

Saturdays Breakfasts on Saturdays were reported to be similar to those served during the week and were either a bread-based meal or a soft porridge prepared from either maize or sorghum meal or oats, served with milk and/or sugar. The accompaniments with the bread, however, often included more expensive foods, such as cheese and French polony. One participant indicated that, due to more time available, she often baked scones for breakfast on Saturdays. For the other meals on Saturdays, different kinds of foods than those consumed during weekdays were indicated. The move seemed to be away from the traditional-type to the more Western-oriented, easy-toprepare convenient food items. Some participants mentioned that lighter meals were prepared, and others included more meat for lunch and or supper. Some indicated food that was easier to prepare such as pap and boerewors, rice and minced meat, or reported that only two meals were prepared instead of three. Chips (French fries) was a popular dish for Saturdays and was served with fish or formed part of the popular Spahtlo, a combination of bread, cheese, French polony and achaar.

Sundays Sundays are regarded as very special days and this was also reflected in the meals that were served. A similar pattern as indicated for Saturdays and weekdays was followed for breakfast for those who ate breakfast. Some however, did not eat breakfast due to religious prescriptions. The elaborate Sunday midday meal can be described as the culinary highlight of the week and this meal received much attention. In most households, rice and/or stiff maizemeal porridge was served with chicken or meat (beef), and at least three different types of vegetable dishes and/or salads were prepared to accompany these. A dessert of either jelly or canned fruit served with custard sauce or ice cream was usually included. Cold drinks such as cordials were enjoyed after lunch. In some households, enough food was prepared for both the midday and evening meals and the leftovers of the midday meal were then served for supper. In other cases, supper was a light meal of bread and tea.

\section{Historical perspective on the evolution of the eating pattern}

Compared to the traditional food habits of the black South African population, the above meal pattern and food choices indicate that marked changes have taken place from those reported in the literature. These changes have taken place gradually but it seemed to have gained momentum from the mid-1960s onward towards a more Western-oriented eating pattern and food choices. The determinants and influences contributing to these changes as reported in the literature and explained by the participants in this study, will be explicated by giving a historical overview of developments and changes that took place during the last century.

The available literature on the eating patterns revealed that the eating pattern and the type of food consumed were very similar for all the different ethnic groups, although minor or subtle differences were noted. A summary of the major changes in the eating patterns as reported in the literature is given in Table 1 and compared to those currently observed in the Mmotla community.

Meal pattern and composition The general pattern followed by all the groups reported in publications up to 1939 was that two meals a day was the norm (Turner, 1909:6; Osborn \& Noriskin, 1937; Ashton, 1939; Bryant, 1939:8). The first meal was enjoyed late morning between 11:00 and 12:00, while the second meal of the day was served after sunset around 17:00 to 20:00. These meals consisted of the ground staple starch (maize) prepared into a stiff porridge served with a relish or side-dish. Researchers are not certain when exactly maize became the principle staple food, but it can be assumed that it must have been since the early 1900s as Turner (1909:6) already mentioned maize as an important staple grain. Other grain sources such as sorghum and millet were however also used extensively (Bryant, 1967:271-272; Schapera \& Goodwin, 1962:131). The type of relish consumed with the stiff porridge was either milk (fresh or sour), or a vegetable relish or legumes. The meal pattern and composition of these meals during the week and over weekends were similar.

This meal pattern and composition seemed to have been followed by most groups up to the mid-1950s, when changes were first noticed with regard to the meal pattern and composition thereof (White, s.a.; Oudkerk, 1965; Walker, 1966). Evidence that the traditional pattern was still being followed, was however, indicated by others (Bruwer, 1963:108-11; Quin, 1964; Mönnig, 1967:188-192; Leary 1969). Reasons for the changes were given as urbanisation, and the increased contact with Western-oriented ways through missionaries and in schools and through the employ- 


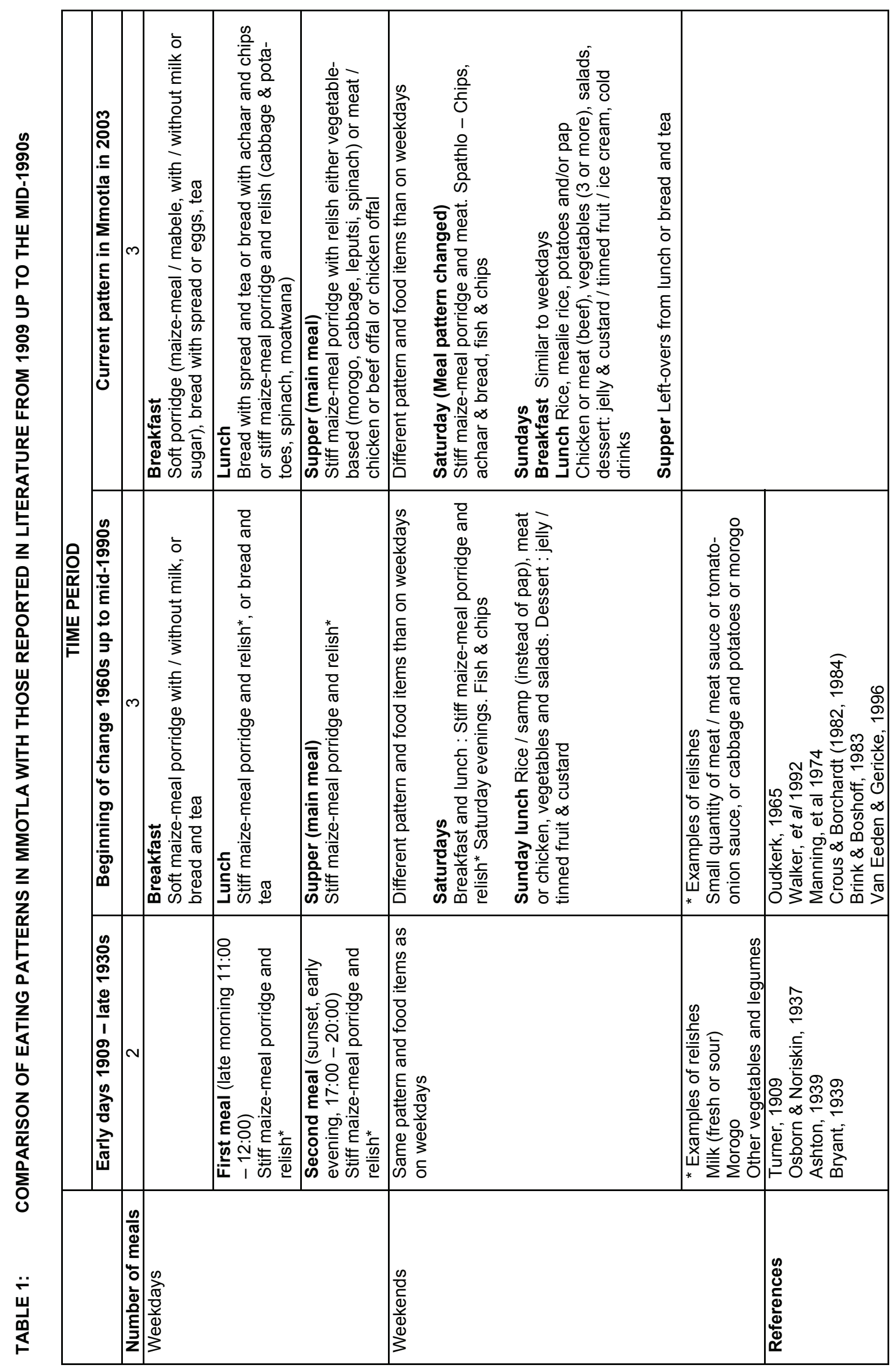

52 
ment of women as domestic workers in white households (White, s.a.; Walker, 1966). The opening of stores in the Reserve areas was another influencing factor and contributed to the introduction of Western food items in these remote areas. In this regard, White (s.a.) observed that the Zulu people in the Valley of a Thousand Hills in KwaZulu-Natal adopted three meals a day and that changes in food preparation methods were also evident, as spices and more fat were now used in the preparation of dishes. The introduction of "modern foods" such as white flour, white bread, sugar, sweetened condensed milk, sweets, cordials, tea, biscuits, buns and cakes, curry powder and chillies, as well as the increased availability of machine ground maize products such as samp, mealie-rice and maize-meal, was reported by White (s.a.). Walker (1966) observed similar trends and admitted that, although information on the dietary aspects of the black population was "relatively scanty" during this time period, some modifications to the traditional diet was noted. The modifications to the traditional diet were attributed to climatic and agricultural conditions that were often unfavourable as a result of intermittent periods of drought, but were most of all due to increased employment and cash earnings that enabled the people in the Reserves and rural areas to purchase Western-types of food products. Those residing in urban areas had adapted to a partly Western diet and enjoyed three meals a day. With regard to the composition of these meals it was reported that although maize-meal was still very popular, bread had now become one of the major sources of energy in the diet of the urban black person. An increased consumption of sugar, meat and milk was also noted. Meat was now included at one or more meals a day. In this comparison between rural and urban people's food consumption, Walker (1966) reported that the urban populations consumed more tea, coffee, soft drinks, fat and tinned foods than those in the rural areas.

Urbanisation The influence of urbanisation continued during the following four decades and became more prominent, as reported in various studies that were done amongst the different ethnic groups. Oudkerk (1965), in a study on the dietary habits of urban black school children in Pretoria, also observed a Western eating pattern during the week, where the consumption of three meals a day was the norm and a different eating pattern during weekends was reported. He reported that on Saturdays fish and chips were popular for lunch. On Sundays some reported that they had no breakfast and that lunch consisted of meat (usually beef), potatoes, samp or mealie-rice, accompanied by three or four vegetable dishes, and a dessert of jelly and custard was also enjoyed. For supper on Sundays, the leftovers of lunch were eaten together with stiff maize-meal porridge. Oudkerk (1965) found, similar to Walker (1966), an increased consumption of milk, the inclusion of meat at least once a day and that brown bread and maize products as well as beverages such as tea and soft drinks were popular. The consumption of eggs was minimal, only $13 \%$ of the study population ( $N=576)$ used eggs once a week, while others indicated a less frequent use, and $46 \%$ indicated that they never used eggs. The use of fats and oils in food preparation was indicated as low (Oudkerk, 1965). Manning et al (1974) conducted a study in Guguletu near Cape Town and found similar tendencies with regard to the meal patterns and the kinds of food items included in meals.

During the 1970s and 1980s, the differences in the dietary pattern between the rural and the urban population groups were still noticeable - as reported in the studies by Lubbe (1971) and Crous and Borchardt (1982, 1984, 1986). In the studies of Lubbe (1971) and Crous and Borchardt (1986), it was observed that in the rural Venda communities the traditional pattern of two meals a day was still followed. Crous and Borchardt (1986) noted that the exceptions were in households with school-going children, where three meals were served and an early morning breakfast was included to provide for children who now had to adhere to set school hours. Maize-meal porridge was the staple food, and was supplemented with relishes prepared from either cultivated or wild greens. Although popular, meat was seldom used as a relish and occurred only occasionally as a delicacy on the menu. Traditional beverages prepared from cereals were still used extensively and Lubbe (1971) observed that only $3 \%$ of the rural participants $(N=266)$ drank tea, and that bread was consumed by only $2 \%$, and when consumed it was not part of a meal but eaten as a between-meal snack. In the 1986 study by Crous and Borchardt, it was found that to a large degree the pattern reported by Lubbe (1971) was still adhered to, with a few changes. Meat was still a scarce commodity and was only consumed a few times per month, as it was not readily available. Bread was regarded as a treat and was used in small quantities compared to maize-meal porridge, and when used it was usually as a supplement to the porridge in a meal. Consumption quantities were calculated to be $530 \mathrm{~g}$ per person in a month (approximately 10 slices of bread). The preparation methods of the sidedishes / relishes were modified in comparison to the traditional: increased quantities of salt, oils and fats as well as vegetables such as onions, tomatoes and potatoes when available, were added to the stewed green leafy vegetables. The degree of inclusion of Western-type foods seemed to depend on the availability and affordability of these items.

The urban groups' food consumption pattern in the above studies by Lubbe (1971) and Crous and Borchardt (1984) could already be described as "semiWestern". Lubbe reported that two and three meals a day were consumed, while Crous and Borchardt (1984) found that three meals a day was the general norm in Atteridgeville near Pretoria for those who were employed, while those who stayed at home had two meals a day. In both these studies it was revealed that maize-meal was still the staple grain and that the meat consumption was considerably higher in comparison to what was reported for the rural communities. Although a vegetable-based relish was still consumed daily, it now formed a minor part of the meal. Lubbe (1971) indicated that in the urban population, bread (mostly white bread) was consumed as a snack 
or as part of the early-morning meal. Crous and Borchardt (1984) found that bread had become an important breakfast item, as $96 \%$ of the participants reported that brown bread was consumed at this meal due to its convenience. Accompaniments to the bread included margarine, jam, peanut butter, eggs and sour milk. Lunch was usually stiff maize-meal porridge with a relish of either meat or vegetables or insects or milk or sour milk. Bread was used to a lesser extent for lunch with similar spreads as indicated for breakfast. The main meal of the day was supper and this consisted of either the popular starch or maize-meal porridge or samp or mealie-rice or rice served with either a meat-based or a vegetable-based relish or fish. A tendency to follow a different meal pattern over weekends was noted by Crous and Borchardt (1984) and was confirmed by other studies in the Pretoria region (Crous \& Borchardt, 1982; Brink \& Boshoff, 1983). Fish and chips were often purchased for the Saturday evening meal and the Sunday midday meal was served as the main meal. This meal was reported as an elaborate meal consisting of meat or chicken served with rice as starch and accompanied by at least three to four vegetable or salad dishes, and ending with dessert in the form of jelly and/or canned fruit with custard sauce.

Changes in the type of beverage consumption were also noted. Lubbe (1971) reported a decreased intake of traditional beverages and the acquiring of the habit of enjoying Western-type beverages such as tea, coffee, Milo and soft drinks. The frequent consumption of tea was also indicated in the study by Crous and Borchardt (1984) where 95\% of the participants indicated that tea was consumed regularly but mainly with breakfast. An increased use of flavourants such as salt, sugar, fats and oils and spices in food preparation, was noted. In a study by Crous and Borchardt (1982), similar trends with regard to meal patterns and types of foods were reported for the urban Pedis.

In other rural communities, changes have also been reported due to influences from environmental changes such as improved infrastructure and socioeconomic circumstances due to employment opportunities in urban areas. The study by Walker et al (1992) evaluating and comparing the consumption patterns of elderly black women in a community in the Magaliesburg region in the former Western Transvaal in 1969, and again 20 years later in 1989, is probably a good reflection of what was happening in other similar South African black communities. Unfortunately, only the type of food consumed was given in this study and no mention was made of the meal patterns. The diet consisted of maize products as staple grain, brown bread, vegetables and fruit in season, and legumes. Dairy produce was consumed only occasionally and meat was included once or twice a week mainly in the form of intestines, chicken and polony. In comparison to 20 years earlier, it was observed that the consumption of maize products had declined and that there was an increase in the bread consumption due to the improved distribution of bread to rural areas and its convenience factor. An increase in fruit and vegetable consumption was noted with, however, the unfortu- nate decline in the consumption of wild greens and legumes. No reason was given for this decline. Also noted was the increased consumption of sugar and fat. It was indicated that the diet of the rural poor blacks changed little from day to day and that all ate similar foods. The improved infrastructure and transport system probably contributed to the observed changes, as it became possible to shop more frequently in nearby rural towns.

During the 1990s, a number of studies reported on the eating patterns of the black population in South Africa. Unfortunately, these studies did not give detailed information on the meal patterns and in most cases revealed only the overall impressions with regard to the consumption of certain food items. The trend of an increase in brown bread consumption was however, noted in a number of independent studies. Steyn et al (1990) compared the eating patterns of rural and urban adolescents of different ethnic groups in the Western Cape during 1985 and found that brown bread was more frequently consumed than stiff maizemeal porridge in both the rural and urban black groups, although maize-meal was rated as a popular food item. In this study, the urban groups consumed a larger variety of food items than was the case in the rural groups. Two studies conducted in the former Homeland of Lebowa reported on the dietary habits of Pedi households. Ladzani et al (1992) also found an increase in brown bread consumption and noticed the popularity of fish and chicken as relishes. Steyn et al (1993) in a study of Lebowa school children confirmed these results and reported that brown bread and maize porridge were regarded as staple foods. Brown bread and stiff maize-meal porridge together with fruit and eggs were the most popular items consumed at school. Large quantities of brown bread and maize were eaten with morogo, cabbage, chicken or tomatoonion gravy, while white bread was consumed in smaller quantities. Tea was the most popular beverage. This study by Steyn et al (1993) confirmed the results obtained by MacKeown et al (1989) and Mackeown et al (1994) on the food intake of school children in the former Transvaal.

In the BRISK study by Bourne et al (1993) in the Cape Peninsula, the conclusion was also drawn that there was a move towards the Western-oriented diet, with an increase noted in the consumption of meat, refined cereal and fat. In contrast to other studies conducted during this time, only $25 \%$ of this study population consumed three meals a day. The meal pattern was described as "erratic", as almost half of the participants ate two meals a day and snacking "contributed considerably to the daily intake". Van Eeden and Gericke (1996) in a study during 1992 amongst student teachers in Home Economics from rural and urban areas in South Africa, reported that three meals a day with in-between meal snacking was the general pattern followed. The main meal of the day was served in the evening and most of the participants revealed that they followed a combination of the traditional and the Western-oriented dietary pattern and admitted a decreased consumption of traditional foods. In a study on the food habits of conscripts in 
the former South African Defence Force during 19931994, most of the participants from the black groups indicated that three meals a day were consumed and similar findings with regard to the Western-oriented food intake were reported (Viljoen \& Gericke, 2001).

\section{Other related aspects to the current food practices}

Serving of meals The informants in the current study indicated that the Western-oriented way of serving all the menu items on one plate - as opposed to the traditional custom of serving the staple grain in one dish and the side-dish or relish in another - was the practice followed in most households. Household members were now seated at a table during meals and ate together as a group. The traditional way of serving meals seemed to have fallen away, although it seemed as if a small minority still follow the old custom where different age and gender groups are formed during meals that then enjoy their meals together.

Celebrations and special occasions The older informants indicated that traditionally only the major celebrations that marked the different life stages such as name giving, initiation, weddings and funerals, were celebrated. Today a number of celebrations and special occasions have been added and in some families, celebrations such as the name giving and initiation have fallen away. With regard to funerals, there seem to be other celebrations that are added and that are celebrated at some time after the death and funeral of a person. For example, the end of the mourning period for a widow is nowadays marked by the celebration where "the black is taken off", usually one year after the death of her husband. The erecting and unveiling of the tombstone has become an important social event and a big celebration is associated with this occasion. It is now also customary to celebrate birthdays, Christmas and New Year's Day. Other social occasions and celebrations mentioned that have become important events are church conferences, baptism and night vigils - these however, seem to be closely associated with the different Church groups to which the informants belong.

With regard to the type of food served at these celebrations and occasions, an interesting trend was revealed. At the traditional celebrations the specific traditional dishes that were customarily associated with these celebrations were prepared and served side-byside with the "modern" more Western-type of foods. On the other hand, at the newer / more modern celebrations the common practice is to serve Westerntype foods. However, certain traditional dishes will always be served at any celebration - be it modern or traditional - and dishes mentioned were the traditional staple food of stiff maize-meal porridge, ting Mabele (sour sorghum porridge) and traditional beer. The reason given for this was that men preferred these traditional dishes and that the satiety value of these was higher as compared to that of the modern food.

Food acquisitions Most of the informants are not in the position to cultivate any crops for own consump- tion, as was the case before they settled in Mmotla. The natural environment of the village severely hampered crop production due to amongst others the poor soil condition, the arid climate and the lack of water. Most households do not have piped water, with the result that water has to be transported in large plastic containers on wheelbarrows from central water points or from neighbours who have boreholes. In times of drought, wild greens are also not readily available in the veld to be gathered. Therefore most of the informants relied on what the local food markets had to offer.

The basic food commodities are obtainable from the village shops. Two general dealers, a butcher, a bakery, and a green grocer are centrally situated. A number of small "spaza shops" and street vendors are also scattered throughout the village. A "spaza shop" is usually operated in a suburb, sometimes in the yard of the owner (it can even be part of the house), and can be described as a small-scale "convenience store" where a limited number of basic food items such as bread, coffee, tea, sugar, condiments, toiletries and cleaning aids may be purchased. Most of the spaza shops sell fresh brown bread that is delivered on a daily basis early in the morning from big bakeries in Pretoria. The informally operating street vendors, on the other hand, offer a wide range of products: anything from electrical appliances, jewellery, sweets, chips, fruit, vegetables and meat can be obtained from them.

Although the basic food commodities are obtainable through these shops and vendors, they are expensive in comparison to the prices asked by shops in Pretoria and the nearby big centre of Mabopane. Some of the informants indicated that they have the means to travel by taxi or with their own transport to purchase some of the non-perishable foods in bulk on a monthly basis at Hypermarkets and big Supermarkets in either Pretoria or Mabopane. The only items purchased locally were the heavy items such as large bags of flour, maize-meal and sugar, and also the perishable items such as fresh meat, fruit and vegetables. The others however, have to solely rely on the more expensive items offered by the local shops and vendors.

Access to electricity Access to electricity and the subsequent ownership of electrical household appliances have contributed to changes with regard to the preservation, storage and preparation methods followed. The food preservation and storage methods seemed to fall into two categories. The indigenous and more traditional food items were still preserved according to the traditional methods, whereas the other more modern Western-type of food items are prepared, preserved and stored by means of the available modern technology. All the households in the village have access to electricity and most are in possession of electric stoves. Refrigerators, however, are owned by the minority and those who do not own one, often store some of their perishable commodities at relatives or neighbours who have refrigerators or deep freezers. 
Although some of the indigenous vegetables were not always readily available due to drought or other obstacles in cultivating them, these were still preserved by means of the traditional method of sun drying when they were in abundance. Other vegetables were stored in the refrigerator by those who have access to one. Meat was not preserved by the traditional method of drying any more (Coetzee, 1982:165), but was frozen when they had large quantities. This was however, seldom the case.

Preparation methods have also changed from the traditional to the more modern Western-oriented way of food preparation. In comparison to the traditional method of boiling meat and vegetable dishes, the following preparation methods were now common practice. Meat was fried in oil or grilled in the oven and more spices were added. Baked products such as scones, queen cakes, and a small cupcake-type of soft cake called "dikuku" were standard items that were baked and served at all special occasions and celebrations.

\section{Factors contributing to the current food practices}

The most prominent themes that emerged from the transcripts with regard to the reported changes related to the immediate natural and technological (manmade) environments that determined and influenced the availability and affordability of food items. The other themes related to the socio-cultural environment, where the influence of the white people, the church and convenience were prominent themes. The other socio-cultural themes may be associated with the different generation groups in the sample. The older participants often mentioned health-related consequences and ethnic identity, whereas the younger participants seemed to be more influenced by social status and education.

Natural and man-made environments Two factors from the natural and man-made environments that influenced the current food practices were the availability and the affordability of food.

Availability Availability seems to play a major role in the type of food that can be gathered, cultivated or purchased and this has a direct influence on the food that is chosen for consumption. The limited availability of indigenous vegetables and grain products was often mentioned as reason for not consuming these as often as had been the traditional custom. It was often mentioned that the lack of water was a big obstacle and the main reason why these crops were not cultivated.

"Then that thing with struggling with the water, because they saw there is no water here to plant the traditional foods."

Other contributing factors were natural ecological factors such as the poor soil condition and climate. However, when the rainfall was good, indigenous green leafy vegetables will be in abundance in the veld and the gardens, and these will then be gathered in spring and summer to be dried and stored for winter months.

$$
\begin{aligned}
& \text { * "Yes you see there is a drought this year, I always } \\
& \text { make at my place here, my place is very small, but it } \\
& \text { has always made a lot of morogo." }
\end{aligned}
$$

It was revealed that when the circumstances are favourable, some people cultivate indigenous crops and these will be sold to the community when available.

\section{* "..... they sell these things and we eat as in the olden days."}

At times indigenous vegetables, especially legumes, are available from street vendors or at markets and sometimes these are bought in bulk from farms where they are still cultivated. The informants purchase these with great enthusiasm when they have the opportunity.

* "Other people bring these things here, you can bring legumes here and we buy it. One, two, three, finish!"

"Nowadays they buy these, there are some people who will go to the farm to buy in bulk and when they come here they sell to everyone."

It became clear that indigenous vegetables were still popular here, as in the rest of Africa (Grockowski et al, 2003), and that the limited consumption of these items was mainly due to their not always being readily available. When people came to live in Mmotla they became dependent on what the stores in the area had to offer, because they were not in a position to cultivate their own crops. They therefore had no option but to adapt their diet and to include the "modern food items" that were available in the local stores.

Affordability One of the other important themes that emerged from the discussions was money and the high food prices. The money available not only determined the kinds of foods that could be purchased, but also the frequency thereof. This largely contributed to the current food pattern on weekend days that differed from those during weekdays. During the week meat, for example, was not eaten on a daily basis and most of the participants indicated that they ate it at most three times a week, because it was too expensive to eat on a daily basis. Therefore the less expensive cuts of meat and more often offal products of chicken and beef (that is of course reasonably priced) would be included on a more regular basis. Crous and Borchardt (1984) and Ladzani et al (1992) reported similar trends with regard to meat consumption. Another reason why more bread-based meals were consumed was related to the affordability of relishes. Food prices determined what was eaten with the stiff maize-meal porridge. Bread was often consumed as a meal at lunch because no relish was needed or less expensive accompaniments could be served with it than would be the case when stiff maizemeal porridge was prepared.

* "As now when the things go up [in price] and become a little bit expensive, we don't have any more 
money to buy something to eat with the porridge in the morning or in the day [lunch] and again in the evening. Then we start to eat bread in the morning and during the day [lunch], and then in the evening we will eat a full meal."

The explanation for the different food and meal pattern over weekends was that more money was available over weekends. Most labourers were paid weekly, on Fridays, with the result that more money was available to spend on food purchases over weekends.

“... even Fridays are special because people get salary and they are happy because they got money and then they can buy anything they want to make them happy."

"Over weekends people come from work and then they have pay. So that is why they buy more food."

It was also explained that expensive items for breakfast such as cheese and French polony were only consumed when money was available, and in most cases this would be over weekends. Others, who received a monthly pension, or where the breadwinner (s) in the household earned a monthly salary, indicated that they purposely set money aside for those extra and or special food items for weekends.

"... during the course of the week there is not enough money ... and the other thing is that most of the people who are working, get paid on Fridays. And those who get paid monthly they don't want to waste it on food in the week."

The number of dishes prepared on a Sunday were determined by the amount of money available.

* "Then on Sundays if I have money left, I will buy all the vegetables."

"... the number of dishes will depend on the available money."

"However, if money is scarce bogobe and morogo will be eaten for Sunday lunch."

It became clear that certain items were only prepared and served when they could afford them, such as meat, dessert and cool drinks. The reason why most celebrations and occasions were celebrated over weekends, and why even children's birthday parties were postponed to weekends, was because more money was available to purchase the extra and special foods needed for these celebrations.

The former staple grain sorghum was still regarded as a special and important grain. However, as a direct result of its price, it was now prepared only on special occasions.

".... but it is just that mabele (sorghum) is so expensive. The packages they are small, you can't buy it in large quantities. Most people will say mabele is the first one [referring to preferred grain]."

It became clear that in this community, food choice and consumption are severely restricted by high food prices. Van Eeden and Gericke (1996) also mentioned that the high cost of certain food items prohibited or restricted the consumption thereof in other black South African groups.

Socio-cultural environment Factors in the sociocultural environment that influence current food practices are the influence of white people, convenience, the influence of the church, ethnic identity, healthrelated aspects, education and social aspects.

Influence of white people A prominent influence contributing to the observed changes in food practices was attributed to women who were employed as domestic workers in white households. Here they observed and/or were taught certain food preparation methods and were also introduced to the food eaten by white people. They admitted that they learnt new ways of food preparation as domestic workers in the white households and then copied the food preparation methods and even taught other relatives and friends the European way of food preparation. Preparation methods of meat, vegetables, and salads were mentioned as well as the baking of cakes, scones and bread.

"Ja, she was working as a domestic [worker]. An old white lady taught her to cook."

This elderly woman could recall all the food preparation techniques she was taught while being employed as a domestic worker. She knew how to can fruit, cook jam and make butter and boerewors. She was taught how to bake and mentioned that she could bake bread, scones and cakes. Another 71-year-old participant who worked as a domestic worker for more than 35 years, explained:

"... changes started when she began working, because she saw how the white people prepared their food on Sundays and then when she was home for weekends once a month she bought some of the food they (the whites) were cooking and made it for her family."

A younger participant, who had never been employed, was taught by her sister how to cook certain dishes.

“... but her sister learnt her a lot, because she used to work as a domestic [worker]. Then she learnt how to cook from her in the weekends when she came home. Then in the weekends she [the sister] will cook for them and serve the food at the table, and then she said the family must come and sit at the table, and the sister taught them how to use fork and knife."

The preparation methods of the indigenous vegetables have also been altered to suit the modern palate. Similar to what Manning et al (1974) reported, increased quantities of oil, spices, tomatoes and onions were also added to dishes prepared from indigenous 
vegetables. Peanut butter replaced ground legumes as flavouring in some traditional dishes. The European-type of vegetables are often served raw or cold as vegetable salads with generous quantities of mayonnaise added to some of them.

Convenience Certain items have been adopted into the diet because of their convenience. The reasons for the high consumption of bread were its availability and convenience (Manning et al, 1974; Crous \& Borchardt, 1984). It was regarded as an acceptable alternative for the staple grain porridge that was otherwise served for either breakfast or lunch. It was quick and easy to prepare and especially when only a few members of a household were present, because it was considered too much of an effort to prepare stiff maize-meal porridge for a small number of household members.

"Bread and eggs are easier to prepare and quicker as when you have to cook pap."

"If you have things to go with bread you need not make pap."

\section{"... it is easier to prepare [serve] bread."}

Certain traditional beverages such as mageu and others such as ginger beer are not prepared as often any more, or have been replaced by more convenient alternatives such as concentrated fruit drinks or cordials.

* "... they change, they prepare things that are quick to prepare."

Manning et al (1974) also mentioned that mageu was replaced by more convenient alternatives such as tea, coffee and mineral drinks.

The preparation methods for meat and vegetables have also changed and it was explained that the traditional preparation method of boiling was too time consuming. Most of the participants therefore fried meat in oil or grilled it in the oven. The same applies to some vegetables, as the boiling of some vegetables (such as cabbage and spinach) has been occasionally replaced by stir-frying, and others are often served as salads.

Church Apart from the well-known prescriptions and proscriptions with regard to food that were imposed on members of certain church groups, there were also some churches that strictly prohibited their members from consuming certain traditional foods. In this regard Schapera and Goodwin (1962:360) gave the example of beer drinking that was strictly forbidden. The participants mentioned that the preparation and consumption specifically of fermented dishes were restricted, and gave this as the reason why some do not use traditional beer or sour porridge any more.

"There was this discussion at the church where some said that if they are not allowed to drink beer, and then they should also not be allowed to use ting [sour porridge]."

Some churches also influence the meal pattern of their members on Sundays because they prohibit them from eating breakfast.

"... they are not allowed to go to church when they eat breakfast because they are not allowed to eat before Holy Communion."

Ethnic identity The older informants were more familiar with some of the traditional dishes and still prepared them when the opportunity arose and at special celebrations / occasions. This was regarded as an expression of their cultural identity, and they explained that they made sure that they got hold of certain expensive and / or scarce ingredients to enable them to prepare these traditional dishes. Examples were given of special traditional dishes that were prepared over the festive season. Family members who were home from the urban areas during this period also requested that these dishes be prepared, because the ingredients were often not obtainable in the urban areas and some of the dishes were very timeconsuming to prepare. It became clear that a degree of emotional value was attached to some of these traditional dishes.

"Morogo and tokomane will be prepared on Christmas, because the relatives from the township, because they don't eat morogo regularly, so when they come here they want to eat morogo. So there will be morogo on Christmas day."

Another participant explained that a special traditional dish "unohlogoza" is prepared for special occasions in her family. She took a lot of trouble to find the specific grade of sorghum and then took great care to grind it herself for this special dish.

They felt that it was important that the younger generation should become acquainted with such customs.

"... they want to show the new generation the Ndebele tradition, their traditional dishes, ... even if they have these special occasions. Each and every special occasion has its traditional dish. So they must know when this traditional occasion, ... this special dish must be served."

In the same vein they pointed out how important it was that a Ndebele woman had to be able to prepare the two kinds of traditional beer "thabalala" and "thodla" properly. This was regarded as the hallmark of "a good Ndebele woman".

One elderly participant was very proud of the fact that her grandchildren enjoyed some of the traditional dishes and they asked her to prepare these during school holidays when they visited her. She explained that her children do not prepare the traditional dishes any more and that she was the one who introduced the grandchildren to these dishes. 
"She feels happy when the grandchildren like the traditional food."

It was a great treat for them when she served these dishes on the traditional grass mats and they were always very eager that she must eat with them on the mat.

“... grandma come and sit down here with us."

Although it was mostly the elderly participants who communicated strong feelings about the conservation of their culinary heritage, some of the younger generation, for instance the scribe, stressed the importance for him to follow the traditions of his ethnic group.

"In my case I won't eat mealie [maize] porridge, only mabele [sorghum]. Then the reason is, it is a spiritual prescription. Because my ancestors have eaten mabele, so I must follow the same path. Then there is no way that I can eat white pap, it does not cover my tradition, so I still eat mabele pap."

The older men were not very fond of the modern Western-type of food and therefore the traditional staple food of stiff maize-meal porridge was prepared for them when some of the modern starch items were served on Sundays and at celebrations. The emotional value that was still attached to the staple food maize was often evident.

"There are older people who still like the traditional food, like her husband. When it is Sunday she will have to cook pap for him, he doesn't enjoy rice."

"The other thing is most men like traditional food, they don't like rice."

Health-related aspects The older informants explained that the reason for including more brown bread in their diet was related to certain illnesses they have or because it is healthy. The local clinic staff told them that it is healthy to eat brown bread.

"Most of the reasons are for the high blood [pressure] where they are restricted to most of [meaning they were advised not to eat] the food such as sugar, white pap and fish oil."

"... so sometimes it is for health reasons that they eat bread"

Others indicated that certain items were included or excluded from their diets because of health reasons.

"Mabele [sorghum] is eaten regularly by some because this is based on the person's health and own rituals."

"Coffee is not good for people with high blood [pressure]."

On the other hand, certain traditional dishes and beverages were not consumed or prepared any more by some of the older people because they do not agree with them any more. One participant told how she loved mageu but does not prepare it any more because it causes heartburn.

Education The older informants were concerned that their children were not adhering to traditions any longer. The younger adult informants revealed that they followed the more modern ways as a result of the influence of education and social aspirations.

"Then the other thing we, ... new generation, we are educated enough that is why we want to eat more food [larger variety] and fancy ones."

Social aspects Similar to other cultures, certain foods were also associated with joyous and special occasions. Weekends were regarded as very special, because this was often the only time that a family or household members could be together. Over weekends friends and families visited each other and almost all celebrations were scheduled for weekends. As explained above, more and special foods were purchased and prepared compared to during the week.

"Sundays ... it is special, because everybody is at home, that is why they cook this special food."

The younger adults associated social status with following the modern Western-oriented food practices. It seemed to be important to follow the professional people such as teachers, lawyers and health-care workers in the community.

"The changes are because we are now mixed together [rich and poor, educated and less educated] so when the rich start to buy rice, vegetables, and the poor then come around, they will start to buy the same stuff, even if they don't have money."

Children often influenced their parents after they had observed how other people behave. One participant explained that her children told her that to sit on the floor during mealtimes was not appropriate any more, and they told her:

"... this is an olden days thing, you can't do it any more."

Another explained how the manner in which food was served changed because her children wanted it that way.

"Since her children grew up they see the other people, [how] they serve food and then it changed. But when her husband was still there [alive] they used to dish up in two plates."

It seemed that the older generation still valued the traditional ways of serving and eating meals, whereas the younger, more educated generation preferred the Western-oriented practices and associated them with being educated. 


\section{CONCLUSION}

The influences contributing to the change and development of food practices with regard to the meal patterns and the composition of meals, were reported. The most prominent influences may be attributed to the natural and man-made environments, while economic / financial influences and influences from the socio-cultural environment are also reflected.

The gradual move towards the more Western-oriented food practices in this community started about four decades ago when this settlement was founded as a so-called Trust Area. The lack of water inhibited the cultivation of indigenous crops with the result that the community has become dependent on purchased food items offered by the local stores. This, together with the increased contact with the Western-oriented life-style of the nearby large cities of Pretoria and Johannesburg and the employment and education opportunities offered by these cities, resulted in adaptations to the traditional food practices.

Although there is evidence that the current food practices in this community are leaning more toward the Western-oriented practices, certain traditional food practices are still adhered to, for example certain traditional dishes are still prepared and these will be available at both the more traditional as well as modern celebrations and special occasions. The traditional staple food, stiff maize-meal porridge, traditional beer and ting mabele (sour sorghum porridge), will always be served at such occasions. The importance of the staple food is evident in the fact that it is prepared at least once a day in most households, and when rice and other starches are prepared, stiff maize-meal porridge will be prepared for the older men who prefer it to the other starches. The influence of some church groups with regard to food prescriptions and proscriptions has also become evident. Certain churches prohibit the consumption of fermented products such as traditional beer and sour porridge, with the result that some people do not prepare and consume these items any more.

Another aspect that has an important influence on the current food practices in this community relates to economic factors and the fact that most labourers are remunerated on Fridays. During the week, the food choices are more limited compared to weekends when more funds are available to purchase meat and other special food items. Meat consumption during the week is therefore limited and offal products of beef and chicken are consumed as relishes instead. Convenience is another important factor in the food choices made. The increased consumption of bread in comparison to the traditional foods is attributed to convenience as well as the affordability of relishes to accompany it. It is easier to serve bread for breakfast than to prepare porridge, and bread is always readily available. Bread could be served with less expensive accompaniments as opposed to the more expensive relishes needed to accompany stiff maize-meal porridge.
In comparison to the traditional practices, food preparation methods have also undergone changes. Convenience and time-constraints as well as access to electricity and electric stoves contributed to these changes. Frying has become a preferred method to cook meat and certain vegetables, and large quantities of oil and fat are used. Vegetable salads and starch-based salads have become very popular and these are often prepared with generous quantities of mayonnaise.

\section{APPLICATION}

Awareness of the above influences could serve as a foundation for effective nutrition education programmes. The insights gained into the current food practices of this community could be used to empower them to alter or improve on some of these practices in order to prevent the negative consequences of the "nutrition in transition". Through nutrition education programmes and consumer facilitation, they could be assisted to find methods to adapt some of their food preparation methods to decrease the amount of fats and oils used. The nutritional contribution of certain traditional and indigenous ingredients needs to be acknowledged and emphasised, and the inclusion and promotion of these ingredients in food preparation needs to be encouraged. Assisting and encouraging the development and adjustment of traditional recipes to appeal more to the modern Western-oriented palate would probably achieve this.

\section{LITERATURE LIST}

ACHTERBERG, C. 1988. Qualitative methods in nutrition education evaluation research. Journal of Nutrition Education 20(5):244-250.

ADLER, PA \& ADLER, P. 1987. Membership roles in field research. London. Sage.

ASHTON, EH. 1939. A sociological sketch of Sotho diet. Transactions of the Royal Society of South Africa 27:157-167.

BABBIE, E \& MOUTON, J. 2001. The practice of social research. South African edition. Cape Town. Oxford University Press.

BETTS, NM, BARANOWSKI, T \& HOERR, SL. 1996. Recommendations for planning and reporting focus group research. Journal of Nutrition Education 28:279-281.

BOURNE, LT, LANGENHOVEN, ML, STEYN, K JOOSTE, PL, LAUBSCHER, JA \& VAN DER VYVER, E. 1993. Nutrient intake in the urban African population of the Cape Peninsula, South Africa. The BRISK study. Central African Journal of Medicine 39(12):238247.

BOURNE, LT, LANGENHOVEN, ML, STEYN, K, JOOSTE, PL, NESAMVUNI, AE \& LAUBSCHER, JA. 1994. The food and meal pattern in the urban African population of the Cape Peninsula, South Africa. The BRISK study. Central African Journal of Medicine 40 (6):140-148

BOURNE, LT \& STEYN, K. 2000. Rural/urban nutrition related differentials among adult population groups in 
South Africa, with special emphasis on the black population. The South African Journal of Clinical Nutrition (February Supplement):S23-S28.

BRINK, A \& BOSHOFF, E. 1983. Babavoeding in GaRankuwa, Bophuthatswana: voedselverbruik en maaltydpatrone. Tydskrif vir Dieetkunde en Huishoudkunde 11(1):9-13.

BRUWER, FP. 1963. Die Bantoe van Suid-Afrika. Hersiene uitgawe. Kaapstad. Afrikaanse PersBoekhandel.

BRYANT, AT. 1939. A description of native foodstuffs and their preparation. Pretoria. Government Printers.

BRYANT, AT. 1967. The Zulu people. $2^{\text {nd }}$ ed. Pietermaritzburg. Shuter \& Shooter.

COETZEE, R. 1982. Funa food from Africa. Roots of traditional African food culture. Pretoria. Butterworths. COLLINS, K. 1999. Participatory research. A primer. Johannesburg. Prentice-Hall.

CROLL, JK, NEUMARK-SZTAINER, D \& STORY, M. 2001. Healthy eating: what does it mean to adolescents? Journal of Nutrition Education 33:193-198. CROUS, JM \& BORCHARDT, S. 1982. Eetgewoontes van Pedi-huisgesinne in Atteridgeville. Tydskrif vir Dieetkunde en Huishoudkunde 10(1):29-31.

CROUS, JM \& BORCHARDT, S. 1984. Dieetpatrone van Venda-gesinne in Atteridgeville. Tydskrif vir Dieetkunde en Huishoudkunde 12(2):41-44.

CROUS, JM \& BORCHARDT, S. 1986. Dieetpatrone van Venda-gesinne in Tshikunda Malema. Tydskrif vir Dieetkunde en Huishoudkunde 14(2):44-47.

DE VOS, AS \& FOUCHE, CB. 1998. General introduction to research design, data collection methods and data analysis. In DE VOS (Ed). Research at grass roots. A primer for the caring professions. Pretoria. JL van Schaik.

FALK, WL, BISOGNI, CA \& SOBAL, J. 1996. Food choice of older adults: a qualitative investigation. Journal of Nutrition Education 28:257-265.

GRUNERT, KG. 1993. Towards a concept of foodrelated life-style. Appetite 21:151-155.

GOCKOWSKI, J, MBAZO'O, J, MBAH, G \& MOULENDE, TF. 2003. African traditional leafy vegetables and the urban and peri-urban poor. Food Policy 28:221-235.

HAMMERSLEY, M \& ATKINSON, P. 1995. Ethnography. Principles in practice. $2^{\text {nd }}$ ed. London. Routledge. KEIM, KS, SWANSON, MA, CANN, SE \& SALINAS, A. 1999. Focus group methodology: adapting the process for low-income adults and children of Hispanic and Caucasian ethnicity. Family and Consumer Sciences Research Journal 27(4):451-465.

LABADARIOS, D (Ed). 2000. National food consumption survey in children aged 1-9, South Africa. 1999. Pretoria. Department of Health: Directorate of Nutrition.

LABADARIOS, D, WALKER, ARP, BLAAUW, R \& WAKER, BF. 1996. Traditional diets and meal patterns in South Africa. World Review on Nutrition and Dietetics 79:70-108.

LADZANI, R, STEYN, NP \& NEL, JH. 1992. A socioeconomic profile of households in semi-rural areas of Lebowa with specific reference to dietary habits. The South African Journal of Food Science and Nutrition 4 (3):60-63.

LEARY, PM. 1969. The diet of Pedi school children.
South African Medical Journal 43:792-795.

LUBBE, AM. 1971. Dietary evaluation. South African Medical Journal 45:1289-1297.

MACKEOWN, JM, CLEATON-JONES, PE, GRANATH, L, RICHARDSON, BD \& SINWEL, RE. 1989. A study of the relative amounts of food items consumed by South African preschool children. The South African Journal of Food Science and Nutrition 1 (3):19-22

MACKEOWN, JM, CLEATON-JONES, PE \& SENE$\mathrm{KAL}, \mathrm{M}$. 1994. Individual food items in the diets of South African preschool children - energy, total protein, carbohydrate, fibre, added sugar and fat intake. The South African Journal of Food Science and Nutrition 6(3):94-98.

MANNING, EB, MANN, JI, SOPHANGISA, E \& TRUSWELL, AS. 1974. Dietary patterns in urbanized blacks. South African Medical Journal 48:485-497.

MILES, MB \& HUBERMAN, AM. 1994. Qualitative data analysis. $2^{\text {nd }}$ ed. London. Sage.

MÖNNIG, HO. 1967. The Pedi. Pretoria. JL van Schaik.

MORGAN, DL. 1997. Focus groups as qualitative research. $2^{\text {nd }}$ ed. London. Sage.

NESTLE, M, WING, R, BIRCH, L, DISORGA, L, DREWNOWSKI, A, MIDDLETON, S, SIGMANGRANT, M, SOBAL, J, WINSTON, M \& ECONOMOS, C. 1998. Behavioral and social influences on food choice. Nutrition Reviews 56(5):S50-S74.

NEUMAN, WL. 2000. Social research methods. Qualitative and quantitative approaches. $4^{\text {th }}$ ed. London. Allyn \& Bacon.

OLTERSDORF, U, SCHLETTWEIN-GSELL, D \& WINKLER, G. 1999. Assessing eating patterns - an emerging research topic in nutritional sciences: introduction to the symposium. Appetite 32:1-7.

OSBORN, TWB \& NORISKIN, JN. 1937. Data regarding native diets in Southern Africa. South African Journal of Science 33:605-610.

OUDKERK, ACF. 1965. Eating habits of urban Bantu, with special reference to the school-going child. South African Medical Journal 39:1148-1150.

PAISLEY, J, SHEESHKA, J \& DALY, K. 2001. Qualitative investigation of the meanings of eating fruits and vegetables for adult couples. Journal of Nutrition Education 33:199-207.

POPKIN, BM. 1994. The nutrition transition in lowincome countries: an emerging crisis. Nutrition Reviews 52(9):285-298.

QUIN, PJ. 1964. Foods and feeding habits of the Pedi. South African Medical Journal (26 December):969971.

REYNOLDS, KD, HINTON, AW, SHEWCHUK, RM \& HICKEY, CA. 1999. Social cognitive model of fruit and vegetable consumption in elementary school children. Journal of Nutrition Education 31:23-30.

SCHURINK, EM. 1998. Designing qualitative research. In DE VOS, AS (Ed) Research at grass roots. A primer for the caring professions. Pretoria. JL van Schaik.

SCHURINK, WJ. 1998. Participant observation. In DE VOS, AS (Ed) Research at grass roots. A primer for the caring professions. Pretoria. JL van Schaik. SCHAPERA, I \& GOODWIN, AJH. 1962. Work and wealth. In SHAPERA, I (Ed) The Bantu-speaking 
tribes of South Africa. London. Routledge \& Kegan Paul.

SPRADLEY, JP. 1979. The ethnographic interview. New York. Holt, Reinhardt \& Winston.

STEYN, NP, BADENHORST, CJ \& NEL, JH. 1993. The meal pattern and snacking habits of schoolchildren in two rural areas in Lebowa. The South African Journal of Food Science and Nutrition 5(1):5-9.

STEYN, NP, WICHT, CL, ROSSOUW, JE, KOTZE, TJ $\checkmark$ W \& LAUBSCHER, R. 1990. The eating patterns of adolescents in the Western Cape. The South African Journal of Food Science and Nutrition 2(2):23-27.

STORY, M, NEUMARK-SZTAINER, D \& FRENCH, S. 2002. Individual and environmental influences on adolescent eating behaviors. Journal of the American Dietetic Association 102(3):S40-S51.

STRAUSS, A \& CORBIN, J. 1998. Basics of qualitative research. $2^{\text {nd }}$ ed. London. Sage.

TON NU,C. MACLEOD, P \& BARTHELEMY, J. 1996. Effects of age and gender on adolescents' food habits and preferences. Food Quality and Preference 7 $(3 / 4): 251-262$

TROLLIP, AM. 1991. Die betekenis van geakkultureerde kledingpraktyke vir geselekteerde NdzundzaNdebele-vroue. PhD-tesis. Universiteit van Pretoria.

TROLLIP, AM.1995. Meaning of blankets, towels and T-shirts in the context of acculturation. South African Journal of Ethnology 18(4):150-154.

TROLLIP, AM. 1997. Towards developing a model for the empowerment of rural South African women. Journal of Dietetics and Home Economics 25(1):2-10.

TURNER, GA. 1909. The diet of the South African Natives in their kraals. Pretoria. Government Printing and Stationery Office.

TURNER, V. 1967. The forest of symbols. Aspects of Ndembu ritual. London. Cornell University Press.
VAN EEDEN, TS \& GERICKE, GJ. 1996. Effect of acculturation on habitual food intake and dietary patterns of rural and urban black home economic students. South African Journal for Food Science and Nutrition 8(3):85-94.

VILJOEN, AT \& GERICKE, GJ. 2001. Food habits and food preferences of black South African men in the army (1993-1994). Journal of Family Ecology and Consumer Sciences 29:100-115.

WALKER, ARP. 1966. Nutritional, biochemical and other studies on South African populations. South African Medical Journal (17 September):814-852.

WALKER, ARP 1995. Nutrition-related diseases in Southern Africa: with special reference to urban African populations in transition. Nutrition Research 15 (7):1053-1094

WALKER, ARP \& CHARLTON, KE. 2001. Nutrition and aging in Africa: transitional changes. Nutrition Today 36 (1):37-42.

WALKER, ARP, WALKER, BF \& WALKER, AJ. 1992. Comparison of nutrient intakes of South African elderly rural black women in 1969 and 1989. Journal of Human Nutrition and Dietetics 5:169-177.

WETMORE, SB \& THERON, F. 1998. Community development and research: participatory learning and action - a development strategy in itself. Development Southern Africa 15(1):29-54.

WHITE, E. s.a. Report on the investigation into the nutritional habits and problems of the Zulu in the Valley of a Thousand Hills. Durban. Department of Nutrition.

WOODWARD, DR, BOON, JA, CUMMING, FJ, BALL, PJ, WILLIAMS, HM \& HORNSBY, H. 1996. Adolescents' reported usage of selected foods in relation to their perceptions and social norms in those foods. Appetite 27:109-117. 